\title{
Primary Ewings Sarcoma of Cavernous Sinus in an Infant: A Case Report and Review of Literature
}

\author{
Bir Infantta Kavernöz Sinüsün Primer Ewing Sarkomu: \\ Bir Olgu Sunumu ve Literatürün Gözden Geçirilmesi
}

\author{
Mohana Rao PATIBANDLA ${ }^{1}$, Shantveer G UPPIN ${ }^{2}$, Amit Kumar THOTAKURA ${ }^{3}$, Manas K PANIGRAHI ${ }^{4}$, \\ Sundaram CHALLA ${ }^{2}$ \\ ${ }^{1}$ Nizam's Institute of Medical Sciences, Department of Neurosurgery, Hyderabad, India \\ ${ }^{2}$ Nizam's Institute of Medical Sciences, Department of Pathology, Hyderabad, India \\ ${ }^{3} N R I$ Academy of Sciences, Department of Neurosurgery, Guntur, India \\ ${ }^{4}$ Krishna Institute of Medical Sciences, Department of Neurosurgery, Hyderabad, India
}

Correspondence address: Panigrahi Manas KUMAR / E-mail: manaspanigrahi@live.com

\begin{abstract}
Ewing's / peripheral primitive neuroectodermal tumor (pPNET) of the cavernous sinus are extremely uncommon. We present clinical, radiological, pathological findings of Ewing's / pPNET involving the cavernous sinus in an eleven-month-old infant presenting with proptosis and 6th nerve palsy. MRI Contrast scans showed a well-defined, homogenously enhancing mass involving the right cavernous sinus location. Histopathology and immunohistochemical features were consistent with Ewing's/pPNET. The patient succumbed to disease in spite of starting chemotherapy. The clinical, radiological and pathological findings of previously reported cases of Ewing's sarcoma / pPNET involving the cavernous sinus are summarized. The histological differential diagnosis of primary intracranial Ewing's sarcoma / pPNET are discussed.
\end{abstract}

KEYWORDS: Ewing's sarcoma, Peripheral primitive neuroectodermal tumor, Cavernous sinus

öz

Kavernöz sinüs Ewing / periferal primitif nöroektodermal tümörü (pPNET) son derece nadirdir. Proptosis ve 6. sinir palsisi ile gelen 11 aylık bir infantta kavernöz sinüsü tutan Ewing/pPNET klinik, radyolojik ve patolojik bulgularını sunuyoruz. Kontrastlı MRG taramaları sağ kavernöz sinüs konumunda iyi tanımlanmış, homojen olarak kontrast tutan bir kitle göstermiştir. Histopatoloji ve immünohistokimyasal özellikler Ewing/ pPNET ile tutarlı bulunmuştur. Kemoterapi başlanmasına rağmen hastamız hastalığı nedeniyle ölmüştür. Daha önceden bildirilen kavernöz sinüs Ewing sarkomu / pPNET vakalarının klinik, radyolojik ve patolojik bulguları özetlenmektedir. Primer intrakraniyal Ewing sarkomu / pPNET histolojik ayırıcı tanısı anlatılmıştır.

ANAHTAR SÖZCÜKLER: Ewing sarkomu, Periferal primitif nöroektodermal tümör, Kavernöz sinüs

\section{INTRODUCTION}

Ewings sarcoma is the second most common bone tumor presenting in childhood. Ewing's Sarcoma (ES)/ peripheral primitive neuroectodermal tumor (pPNET) are considered together as a single ES/pPNET family group as both types share common histopathological, immunophenotype and genetic abnormalities (1,2). These can occur at several extraosseous sites like chest wall, head, neck, soft tissues of extremities and in any viscera. Primary intracranial ES/ pPNET has been uncommonly reported at jugular foramen, cerebellopontine angle, frontal dura, tentorium and cavernous sinus $(3,4,8,10)$. Cavernous sinus location is extremely uncommon with only a few cases reported in literature till date $(3,4,8,10)$. We present clinical, imageological and pathological findings of one such case in an eleven month old infant along with review of previously reported cases.

\section{CASE REPORT}

An eleven month old infant was brought by parents with a 10 days history of proptosis and medial deviation of right eye. Examination confirmed right sixth nerve palsy with proptosis. Complete haemogram was done and the values were in normal range. Bone marrow biopsy was done which was showing normal morphology. CT scan and MRI Contrast scans showed a well defined, homogenously enhancing mass measuring $1.8 \times 3 \times 2.1 \mathrm{~cm}$ involving the right cavernous sinus location with mass effect over adjacent right medial temporal lobe medially. The lesion was also abutting cavernous part of right internal carotid artery (ICA). Anteriorly, the lesion was causing widening of right superior orbital fissure with possible extension into the orbit and posteriorly, it was abutting and posteriorly displacing right trigeminal nerve (Figure 1A, B). Radiological differential diagnosis included neuroblastoma, 
hemangioma, lymphoma, undifferentiated small round cell tumor and meningioma.

Debulking of the tumor was done by right frontotemporal craniotomy through subtemporal approach. The lesion was found in the cavernous sinus after opening the parkinsons triangle in the lateral wall. The tumor was vascular, non suckable. Frozen section revealed small round cell tumor. Patient had an uneventful postoperative period and was discharged on fourth post operative day. Histopathological examination revealed a highly cellular tumor comprised of sheets of monotonous round cells with round hyper chromatic nuclei and scant cytoplasm (Figure 2A, B). Mitotic activity as well as foci of necrosis was noted. On immunohistochemistry, the tumor cells showed diffuse strong membrane positivity for CD99 (Figure 3A) but were negative for CD 45 (Figure 3B), terminal deoxynucleotidyl transferase (TdT), glial fibrillary acidic protein (GFAP) and desmin (Figure $3 C$ ). These features were consistent with diagnosis Ewings sarcoma/pPNET. EWSFLI 1 genetic analysis confirmed the diagnosis of Ewing's Sarcoma/pPNET.

Post-operative scans done 2 weeks later showed residual tumor confined to right cavernous sinus. Bone scan, CT scan of chest, abdomen \& pelvis, bone marrow aspiration, MRI scan of spine and CSF cytology showed no evidence of systemic involvement.

The patient advised adjuvant chemotherapy consisting of alternating cycles of doxorubicin, vincristine and cyclophosfamide with ifosfamide and etoposide according to pediatric oncology group protocol. Patient received one dose of doxorubicin, vincristine and cyclophosfamide regimen. The patient died on $37^{\text {th }}$ post operative day at his home due to status epilepticus according to patient attendants.

\section{DISCUSSION}

Ewing's Sarcoma is an undifferentiated small cell neoplasm, sharing immunoreactivity and several fusion genes with pPNET, but pPNET is defined as having further differentiation $(1,2)$. Both ES/pPNET family tumors believed to be derived from neural crest cells (5). Primitive neuroectodermal tumors can be broadly divided into 3 categories, namely, peripheral PNETs, central PNETs, and neuroblastomas, including tumors arising from autonomic nerves. World Health Organization classification of tumors on nervous system recommend the use of PNET selectively to the Medulloblastoma (PNET-MB) and other round cell tumors in nervous system are called as pPNET.

Primary intracranial ES/pPNET is uncommon and cavernous sinus involvement as noted in our case is exceptionally rare (3, $4,8,10)$. The clinical, Imageological and pathological findings of previously reported cases of ES/pPNET involving cavernous sinus are summarized in Table I.

Out of the four cases reported in literature two were male and two were female with age ranging from 13 to 48 years, our case is peculiar in view of extremely young age at presentation. Of the four reported cases one of them was considered to be metastatic (10) as patient was found to have similar tumor with

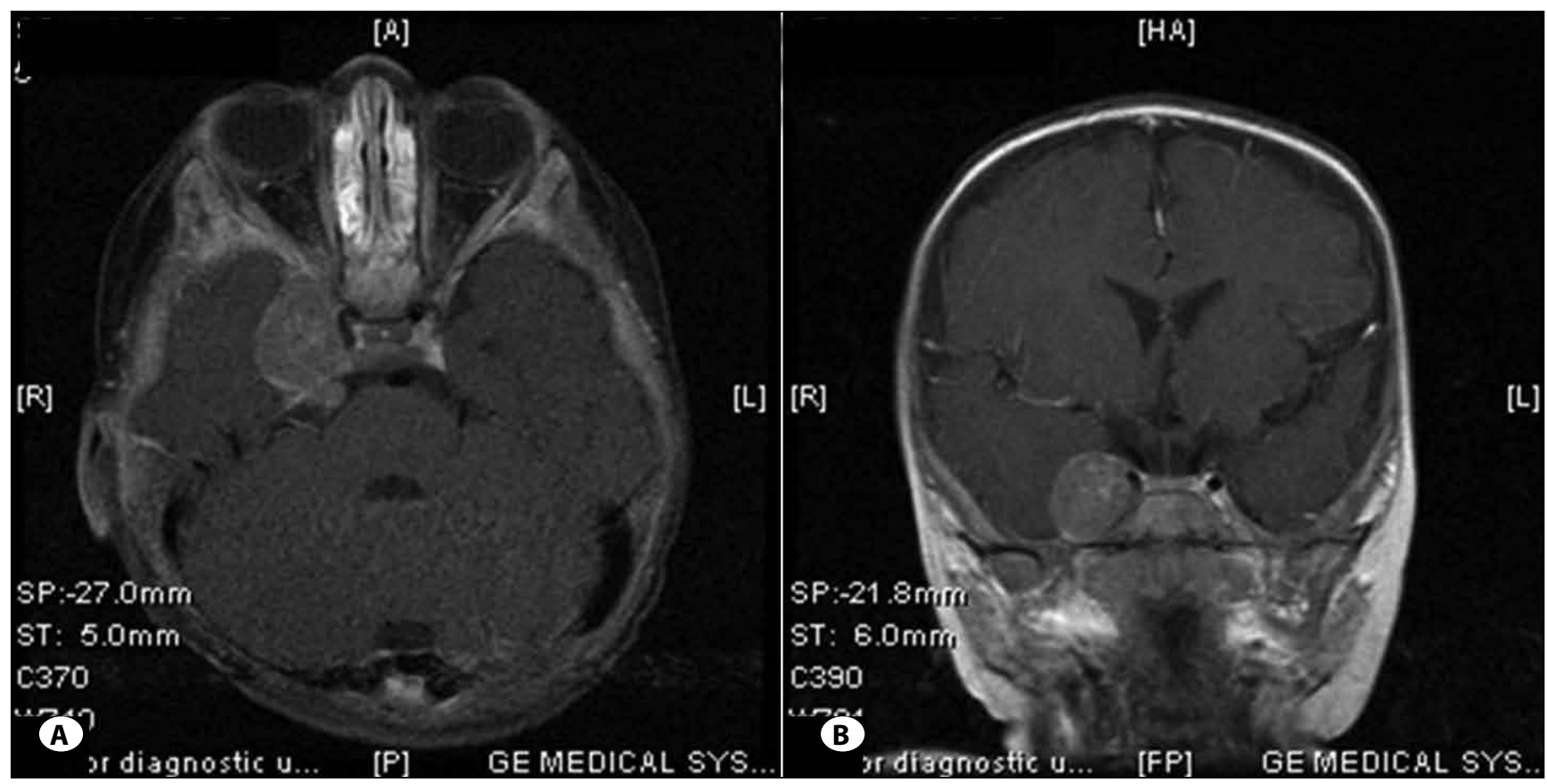

Figure 1: MRI Contrast scan (A) Axial and (B) coronal show well defined, relatively homogenously in right cavernous sinus location with mass effect over adjacent right medial temporal lobe laterally; medially the lesion is abutting cavernous part of right ICA. Anteriorly, the lesion is causing widening of right superior orbital fissure with possible extension into the orbit. Posteriorly, the lesion is abutting right trigeminal nerve with posterior displacement. 


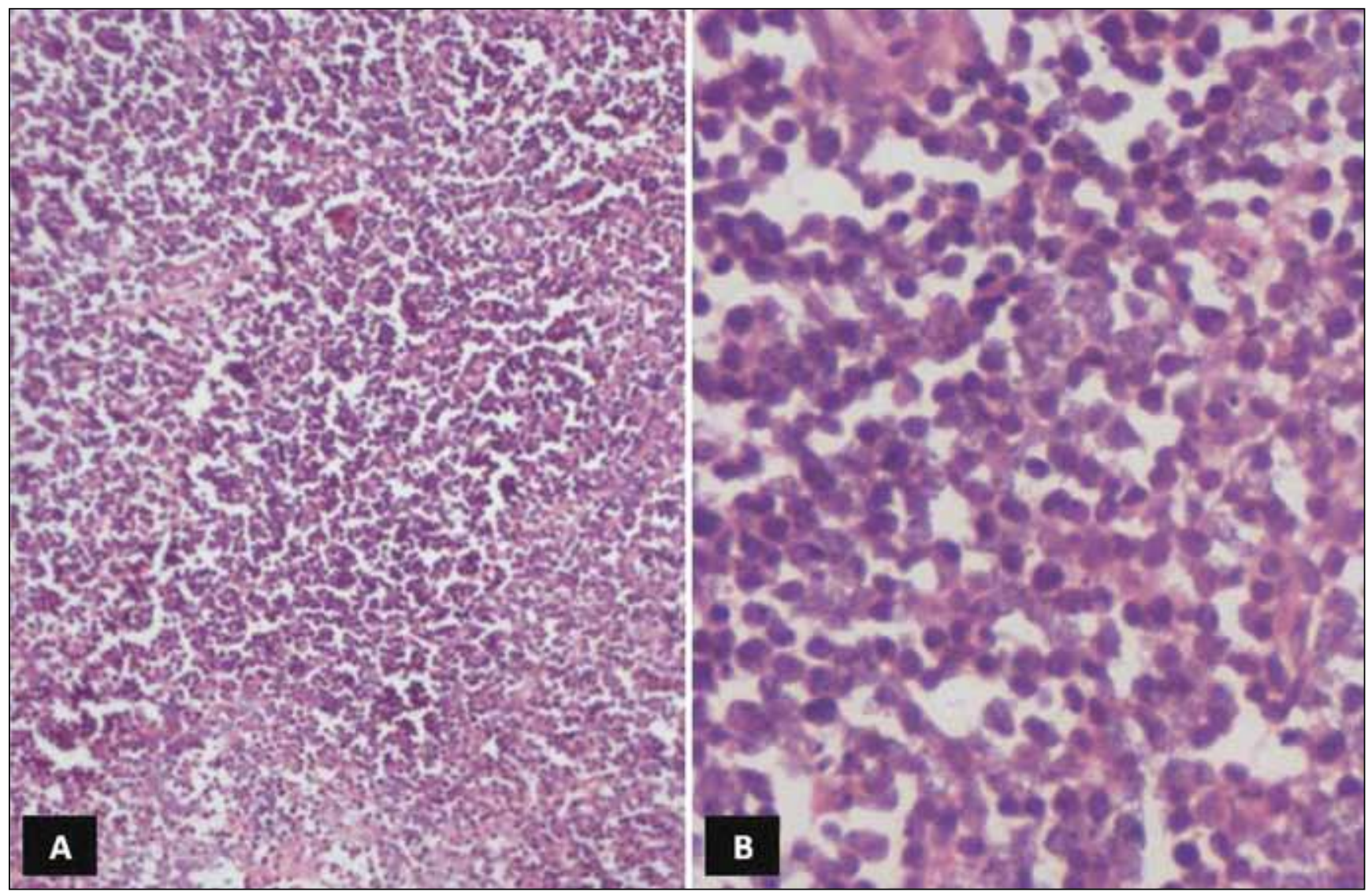

Figure 2A,B: Histological section showing a highly cellular tumor comprised of sheets of monotonous round cells with round hyper chromatic nuclei and scant cytoplasm. (H\&E stain; AX100, BX200).

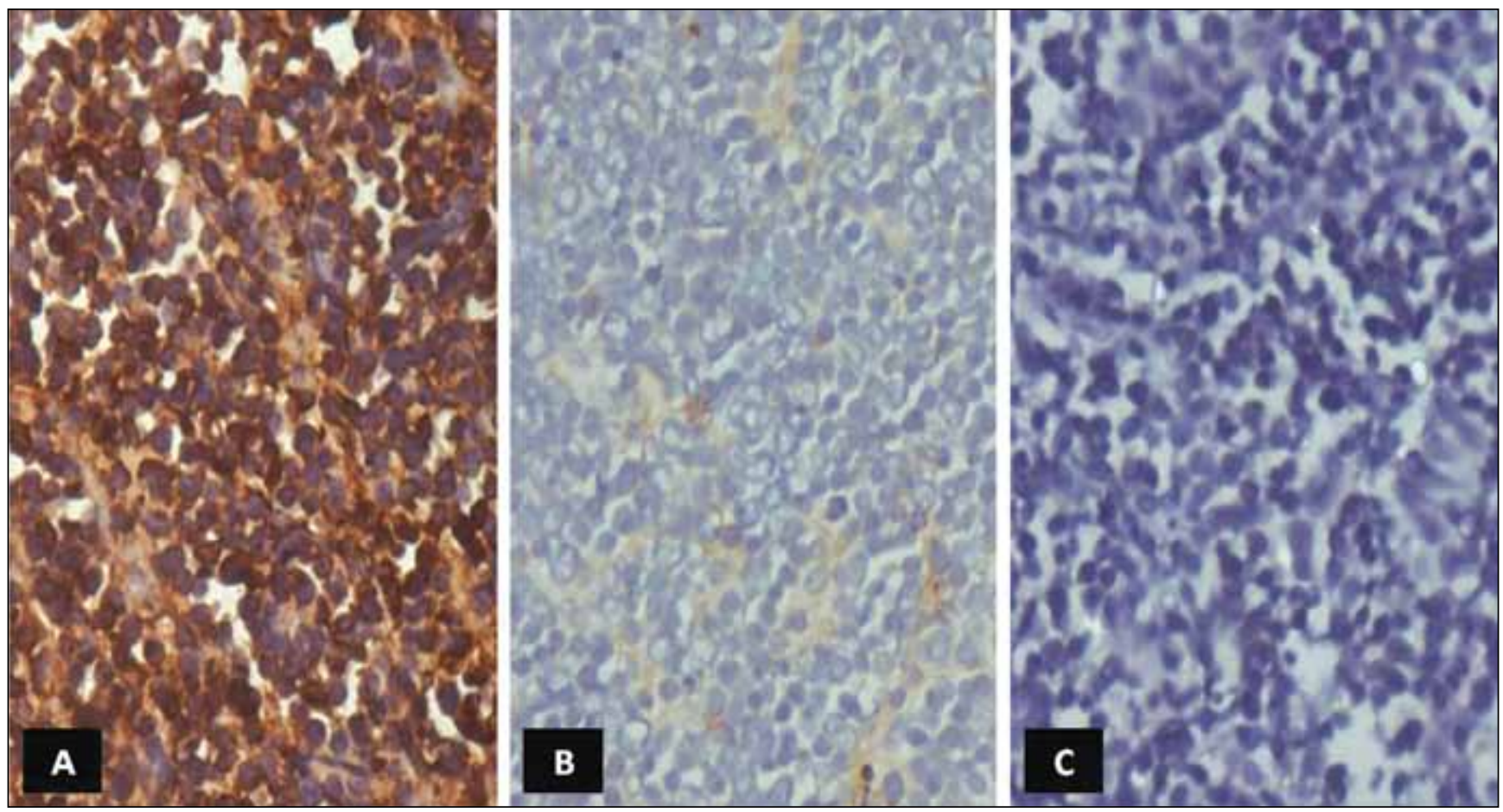

Figure 3: Immunohistochemistry with (A) CD 99 showing diffuse strong membrane positivity in the tumor cells and negative staining (B) CD 45 and (C) desmin. (Polymer-HRP; X 200). 


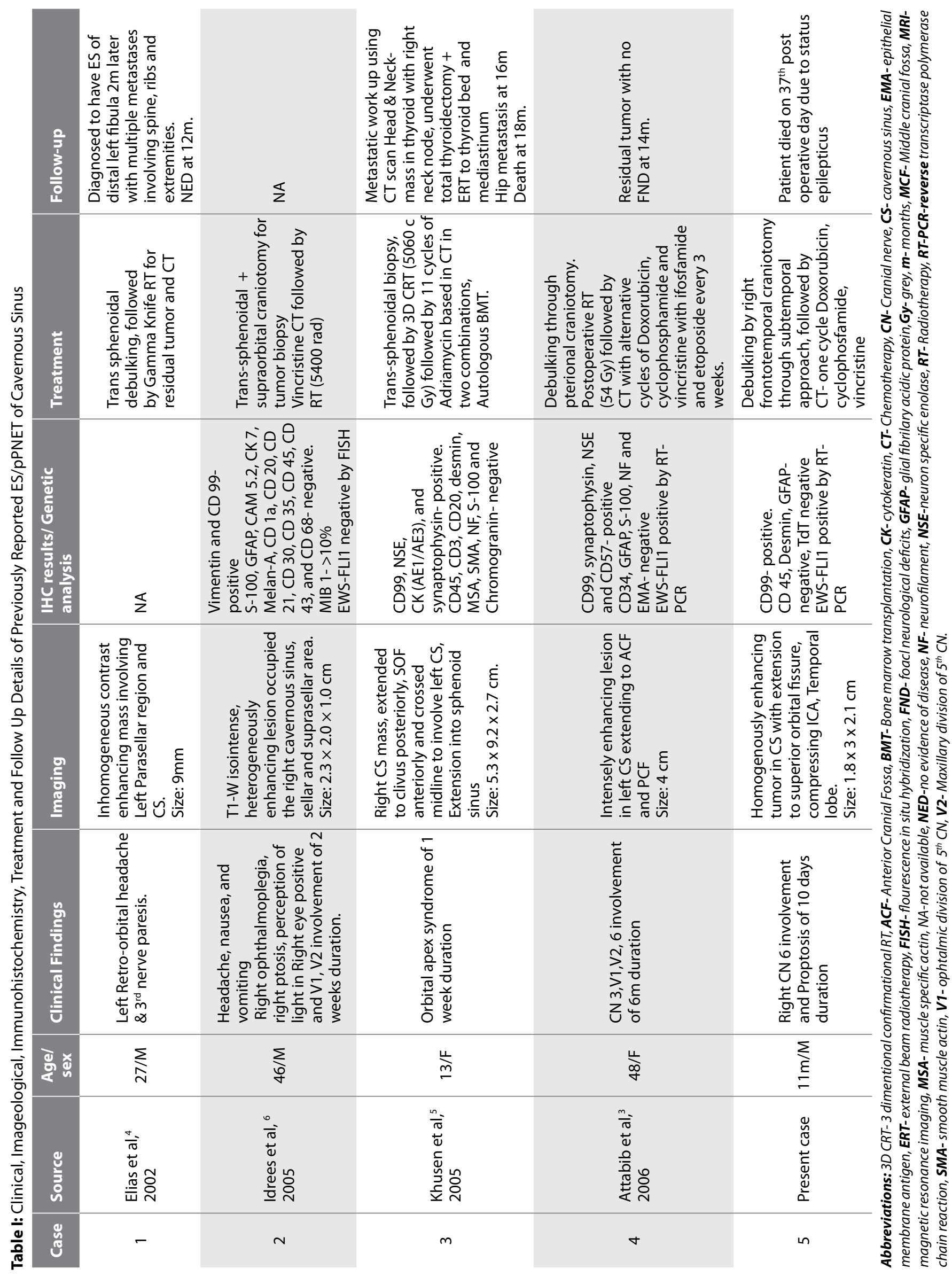


in fibula at later date. The remaining three were considered to be primary ES/ pPNET of cavernous sinus. The case presented here also appears to be primary lesion as there was no evidence of any other primary lesion even after extensive work-up. All cases presented with involvement of one or more of the cranial nerves with in or near to the cavernous sinus like II, III, IV, V and VI. Our patient had involvement of the $\mathrm{VI}^{\text {th }}$ cranial nerve. Radiologically, all the reported cases including the present case showed nonspecific findings with homogeneous or inhomogeneous contrast enhancing lesion without any characteristic features. The diagnosis of ES/pPNET is very difficult on radiological imaging and is purely based on histopathological, immunohistochemical and molecular genetic analysis (3).

The histological differential diagnosis of primary intracranial ES/pPNET includes central PNETs (medulloblastoma, central neuroblastoma, and other neuroepithelial tumors), meningiomas of small cell type, anaplastic gliomas, melanoma, lymphomas, rhabdomyosarcomas, and atypical teratoid/rhabdoid tumors (8). To consider the diagnosis of ES/pPNET there should be presence of two neuronal markers like synaptophysin, neuronal specific enolase, CD 57, CD 99 or Homer-Wright rosette and absence of GFAP, EMA, Desmin, smooth muscle actin \& LCA $(2,6)$. Most of the tumors including the present case showed CD 99 positivity except the case reported by Elias et al where IHC findings are not provided.

EWS-FLI1 (85\%), EWS-ERG (10\%), EWS-ETV1 (rare), EWS-E1AF (rare), EWS-FEV (rare) are different types of translocation fusion genes seen in ES/pPNET family tumors. Of these EWSFLI1 is important for both diagnosis and prognosis. This translocation will result in fusion gene DNA binding domain of FLI1 or ERG is replaced by glutamine rich EWS gene, which is seen in $85 \%$ cases of ES/ pPNET family tumors and detected by reverse transcriptase PCR or FISH (fluorescence in situ hybridization) (9). The central PNETs can be confirmed by absence of CD99 expression and $t(11 ; 22)$ translocation (7). Of the four reported cases of cavernous sinus ES/ pPNET molecular genetic analysis was done in two cases $(3,8)$ with EWS-FLI 1 positivity in one of them (3). Present case showed EWS-FLI 1 positivity like reported one. Central PNETs differ from ES/ pPNET by absence of CD99 staining and $t(11 ; 22)$ (7). Lesions like lymphoblastic lymphoma, astrocytic lesions, alveolar rhabdomyosarcoma, and ependymoma may show limited expression of CD99, they should be excluded by histological and immunohistochemical characteristics (6). In this present case the possibility of above said lesions was ruled out in-view of negative staining for CD45, TdT, desmin and GFAP.

ES/pPNET family tumor is aggressive in nature and warrants an aggressive approach, which usually includes radical surgery, radiotherapy and chemotherapy (5). Wide surgical resection margins at the time of primary surgery have markedly reduced local recurrences. Furthermore, the prognosis depends on several factors, such as tumor location, extension, resection, and the presence of metastases at the time of diagnosis (4). Radical removal is not possible in cavernous sinus in view of its highly vascular nature and close association with cranial nerves, so debulking is the possible modality (4). Role of radiotherapy is mainly for the residual tumor and usual radiation is $56 \mathrm{~Gy}$ (5). In view of patient age and deleterious side effects of radiotherapy on developing brain we planned multiagent chemotherapy with alternating cycles of Doxorubicin, vincristine and cyclophosfamide with ifosfamide and etoposide, which had shown favorable results in previous studies (5). Unfortunately, our patient died after receiving only one cycle of chemotherapy.

Bone scan, CT scan of chest, abdomen \& pelvis, bone marrow aspiration, CSF cytology and MRI scan of spine should be done to rule out metastasis before initiating the treatment (3). The follow-up period in the reported cases has ranged from 12 to 18 months, with death at 18 months in one due to multiple metastases (4). Of the other two cases where follow-up is available one was doing well without evidence of disease at 12 months, whereas the other was symptom free with residual tumor at 14 months. In our case patient died on $37^{\text {th }}$ post operative day with status epilepticus. The number of cases of cavernous sinus ES/ pPNETs reported is few and follow up period has been too short to draw any conclusion regarding the prognosis of these lesions.

\section{REFERENCES}

1. Ambros IM, Ambros PF, Strehl S, Kovar H, Gadner H, SalzerKuntschik M: MIC2 is a specific marker for Ewing's sarcoma and peripheral primitive neuroectodermal tumors. Evidence for a common histogenesis of Ewing's sarcoma and peripheral primitive neuroectodermal tumors from MIC2 expression and specific chromosome aberration. Cancer 67(7):1886-1893, 1991

2. Antunes NL, Lellouch-Tubiana A, Kalifa C, Delattre O, Pierre-Kahn A, Rosenblum MK: Intracranial Ewing sarcoma/'peripheral' primitive neuroectodermal tumor of dural origin with molecular genetic confirmation. J Neurooncol 51(5):51-56, 2001

3. Attabib NA, West $M$, Rhodes RH: Peripheral primitive neuroectodermal tumor of the cavernous sinus: Case report. Neurosurgery 58(5):E992, 2006

4. Dagher R, Pham TA, Sorbara L, Kumar S, Long L, Bernstein D, Mackall C, Raffeld M, Tsokos M, Helman L: Molecular confirmation of Ewing sarcoma. J Pediatr Hematol Oncol 23(4):221-224, 2001

5. Elias B, Uhl E: Intra and parasellar manifestation of an Ewing's sarcoma before detection of the primary tumour. Acta Neurochir (Wien) 144:747-748, 2002

6. Fellinger EJ, Garin-Chesa P, Triche TJ, Huvos AG, Rettig WJ: Immunohistochemical analysis of Ewing's sarcoma cell surface antigen p30/32MIC2. Am J Pathol 139(2):317-325, 1991

7. Kushen Medina, Gulbahce H Evin, Lam Cornelius H: Ewing's Sarcoma of the Cavernous Sinus: Case Report. Neurosurgery 56(6):1375, 2005 
8. Muhammad Idrees, Chirag Gandhi, Simone Betchen, James Strauchen, Wesley King, David Wolfe: Intracranial Peripheral Primitive Neuroectodermal Tumors of the Cavernous Sinus: A Diagnostic Peculiarity. Archives of Pathology \& Laboratory Medicine 129(1):11-15, 2005

9. Sandberg AA, Bridge JA: Updates on cytogenetics and molecular genetics of bone and soft tissue tumors: Ewing sarcoma and peripheral primitive neuroectodermal tumors. Cancer Genet Cytogenet 123:1-26, 2000

10. Windfuhr JP: Primitive neuroectodermal tumor of the head and neck: Incidence, diagnosis, and management. Ann Otol Rhinol Laryngol 113(7):533-543, 2004 